\title{
CIVIL AND CRIMINAL RULES OF THE BABYLONIAN LAW
}

\author{
Ion Țutuianu \\ ”Vasile Alecsandri” University of Bacău \\ tutuianuion@yahoo.com
}

\begin{abstract}
By its age and principles, Babylonian law has drawn attention of all epochs, laying at the basis of scientific development of modern law. The regulation, more than 4000 years ago, of property, family, obligations, public administration, succession, probation principle, represents the proof that the institutions which today regulate these aspects, have been a preoccupation for mankind ever since its beginning. Even if penalties were distributed depending on social status, a progressive element is represented by the fact that the act could only be punished if it met the condition of intent. The legal monument of this system of law, Hammurabi Code, has an important signification by the fact that upon that date, the law and the judges aimed at ensuring life to citizens and to guarantee them certain rights, considerably more than other countries in the epoch. It is striking that in antiquity, the right of succession lies all the children regardless of the number of marriages and criminal aspect beyond class character, crimes regulation retained the substance, the changes incurred on penalties take into account the evolution of human rights, as how malpractice mutilation was replaced by pecuniary or administrative penalty.
\end{abstract}

Keywords

Babylonian law; criminal; civil; successions; Hammurabi

\section{JEL Classification}

N3

\section{Regulation of property}

It is well-known the fact that the oldest Code of law belongs to Hamurabi. Dug on a diorite stone, in Akkadian, its application for approximately 1000 years generated a rich jurisprudence in the ages to come (Drimba, 2003). Within the 282 articles are regulated: property, public administration, trade and obligations, family law, criminal law, maritime law. Like in other countries in the East, the king was considered the rightful owner of the land and depending on the services rendered he would award soldiers and officers a surface which they could not alienate, but which they could lose if the holder refused to fulfil their duty to the king by participating in battles. In case of death in war, the land would be transferred to the eldest son who would also receive the obligations towards the king. Now it is also the time when private property is shaped, regarding houses and orchards, which did not depend on the king. Another part of the land was the property of village communities, for which they had to give a part of the harvest. Both categories of land owners had the duty of executing certain community service activities, such as: maintenance of canals, crossing fords, roads; the king has the right to grant exemptions by written mentions on the milestone.

\section{Regulation of contracts}

The matter of obligations enjoyed a careful regulation in the Babylonian legislation, by numerous categories of contracts. Within the sales-purchase contract, concluded 
with the agreement of the parties, the procedure consisted of the buyer hitting with a stick the object bought, as sign of purchasing the property. Numerous contracts mention the guarantee against eviction, ensuring the buyer of the peaceful use of work against the action of third parties. Many formalities of the sales contract were cancelled in time, because they would harden the conclusion of conventions. The forms of practice indicate a series of rules regarding sales, which, however, did not have a general availability.

The lease contract had an application, no less important. The rental of buildings was practiced on a very large scale by the rich, who made big profits out of these. Besides the rental of buildings, is also known the rental of animals, boats, grain barns etc. An important part is played by the lease contract of orchards and farmland. The richest would often lease land in exchange of a large amount of money or goods, established by law. The rental of personal work also represents the object of many contracts. Free workers could lease their labour and were supposed to receive daily an amount of money. In contract are stipulated conditions that bring advantages to the creditor, if the one selling his work does not work during the entire time he was hired for, he is not paid, not even for the work he has done. In certain conditions it is stipulated that the employee receives an advance, and, in this case, if the interrupts work, he is turned into slave (Craiovan, 2001).

Another contract with economic purpose, even more important, is the loan, known in the Babylonian law from the ancient times (Constantinescu, 2004). The „damcars”, as the usurers were called, would lend money to those in need of it. Those who failed to pay the debt became slaves. However, the code of Hamurabi brings certain improvement in this regard as well, forbidding transformation of debtors into slaves. Thus it was regulated, that, if a debtor fails to pay the debt, he, his wife or his child, could be taken to the creditor's house and work for 3 years, or, if he paid sooner, until the date he paid. The creditor was not allowed to make his own justice, as in this regard, under the law, he loses his debt. In case of natural disasters, which cause serious crop losses, the debtor is exempted from interests for that year and his due date may be delayed. Hamurabi also offers other provisions, helping debtors, as in not all people turn into slaves, from free people, as in this way there would be no army left, as slaves were not recruited for military service. This contract was often accompanied by the stipulation of large interests name sibtu. The code of Hamurabi sets as object of the loan agreement money and barley. This product was considered, in the most possible general meaning, as food, in general, meaning any kind of grain, fruit etc. The fact that barley is given as example, it is explained by the fact that this cereal played the most important in the feeding of the people and animals of that distant era.

Also known from a distant era are the Company contracts. These contracts have as object different trading or agricultural operations, when more people get together to harvest a land, being necessary a written document, drafted in front of witnesses to prove the contract. At the time of dissolution of the company, common assets would be distributed between the shareholder, according to the agreement made at the time of concluding the contract. Another contract discussed is the deposit contract, consisting of the deposit by a certain person of an asset, to be kept by a different person. According to the provisions of Hamurabi, the deposit must be made in front of witnesses. If the person receiving the asset to keep it fails to return it, must pay twice its value. There were two kinds of deposits: the deposit itself and crop deposit. In this latter case, the code establishes an exact tariff for the payment of storing the crop in the storage-barns. 
The amount of the interests was too high, representing an important income for usurers, the percent was of $20 \%$ for loans of money and $33 \%$ for loans of cereals. In order to guarantee his debt, the creditor may ask the debtor a guarantee, either real, either personal. Real guarantee could include either real estate assets, agricultural funds or buildings. In case of agricultural funds, the guarantee is a pledge of use, and in consequence, when the land, due to natural disasters, bears no fruit, the creditor shall not be able to cash the corresponding interests; that is why the law decides that that year is not taken into account for the duration for which the pledge of use was established. In this way, the interest of the creditor is guaranteed. If the land is guaranteed by the debtor provided that it is harvested, the guaranteeing creditor has the right to keep from the crop the value of the capital, of the interests and the investment expenses.

The guarantee can also have as object movables: slaves, children and the wife of the debtor, mobile works etc. The asset given in pledge was not always given to the creditor; it would often remain in the possession of his debtor, sometimes, to a third person. The creditor shall not be able to exercise his right over the asset given as pledge by the simple fact of maturity, but it is necessary to ask permission of justice for this. Thus, the code provides the obligation to repair the damages caused to irrigation installations due to negligence, responsibility for cutting a tree from a foreign orchard etc. Often, for the payment of capital, the pledge was a person (bail); sometimes the bail would guarantee the creditor only under certain conditions (for ex. Only in case of disappearance of the debtor etc). Babylonian law also knows obligations based on crimes, meaning that if somebody causes damages to another person, for him arouses the obligation to refund the damage caused.

\section{Family Law}

The foundation of marriage provided a written contract, concluded in front of witnesses, by which the husband establishes unilaterally the rights and obligations of his wife to be. Usually, marriage was proceeded by engagement and consisted, besides regular gifts, also in an amount of money, which the fiancée gives to his father-in-law. Engagement has legal status: if the fiancée breaks the engagement, he loses the money, and if the girl breaks the engagement, she shall be obliged to refund the double. Often the father of the girl, or in his absence, her brothers create a dowry (seriqtum), it usually exceeds by far the terhatum. The dowry remains the property of the woman, the man only having use of it Upon the death of the woman, the dowry is transferred to the children, and in their absence, to the family of her father. If the marriage is dissolved by divorce, the woman shall receive the dowry, except for the case the marriage was dissolved due to her fault, when she looses her dowry and is punished. But if the marriage is dissolved not because of her fault, the wife shall receive from the husband a part equal to the one of a child and if from the marriage resulted no children, she shall receive an amount equal to the terhatum (in absence of the terhatum she shall receive the amount of one mina). Moreover, the widow has the right to live in the family's house. The spouse, prior to marriage, could have contracted debts. In this case, the wife has to bear the debts of the husband, except for the case when at the time of their marriage the contrary is not specified; however, the husband in not obliged to in the same way for the debts contracted by the wife prior to marriage. In return, for debts contracted during marriage, the spouses are jointly liable. The married woman has a sort of legal capacity. She may be witness, may hold own assets of which she may dispose as she pleases and in absence of the husband she may manage his fortune, if he does not have a major child to take care of this. 
Donations between spouses are allowed. Thus, the husband can make a donation to his wife in order to assure her existence after his death. This donation is called nudunnutn, on such property the woman has only the right of usufruct. Also, liberals could be made to sons or daughters whom the father wanted to protect. The man has certain rights over the woman. He may sell the unfaithful woman as punishment, and when he is deeply in debt he can give her as slave to the lender (in which quality she cannot stay for more than three years). The woman owes the man conjugal fidelity .The woman surprised in the act of adultery is punished by death, by drowning. In addition to the act, she can be exonerated either by oath or by an ordeal , that of throwing himself into the river, which, if it finds her immoral, will drown her. If the husband was taken prisoner and if his wife does not have the necessary for the daily life, the woman can leave the house or not keep her body "without being considered adulterous. Upon the return of the husband the woman may return home; however, the children will stay with their natural father. A husband who left town, and then his wife entered another house, cannot take back his wife because he despised the town with his departure.

The man can divorce his woman anytime: in this case, as we have seen, he is obliged to refund the dowry, and a part of his own property, and if the woman was guilty of separation, she looses the right even on her dowry. At first, the woman could not file for divorce, this was allowed in the era of Hamurabi only in certain cases, such as abandonment, unworthy behaviour of the husband and refusal of joint cohabitation (Hanga, 1977). If the reasons are justified, the woman is allowed to break off, and if no justifiable reason, she tool legal action against her husband, she will be punished by drowning.

Marriage is generally monogamous; the husband may have only one wife. The husband may repudiate his wife, if after a certain time of joint cohabitation it turns that she can bear no children. The general formula of repudiation is "I repudiate you" or "you are no longer my wife". The woman repudiated for sterility, shall receive her dowry and the other right she is entitled to under the law. Sometimes, the husband keeps the sterile wife and takes another woman, who shall not have the same legal and social status as his wife, but that of an inferior wife. Still, in case of repudiation, she will have the rights of a lawful wife, and the children she will born shall have the capacity of lawful children. Sometimes the wife, whether she gas children or not, can give her husband a slave concubine who shall be fully emancipated if she gives birth. She can be brought again to slavery if she pretends to be equal to the lawful wife. Accepting the situation above, the husband cannot introduce another wife to his home, even if the concubine is sterile.

Although the husband has discretionary power in repudiating his wife, he cannot repudiate his wife if she is infirm or suffering from a chronic disease; in this case the husband is allowed to have another wife and the first one can either return to her family, either continue to stay with her husband.

The discretionary power of the man in matter of repudiation is sort of sweetened by the rights provided to the repudiated wife, without any fault on her side. If the woman was repudiated for immoral behaviour or bad management of the home, often besides the fact that she looses the rights provided by law for the repudiated wife, she is brought back to slavery in the house of her ex-husband.

Regarding barriers to marriage we reported hindrance for any citizen to marry a woman dedicated to the temple (god's possession has an exclusive character). Another impediment is of a somewhat curious characteristic: if the father-in-law does not allow the engagement for a bad reputation of the suitor, his daughter cannot become his wife. Finally, another obstacle is similar to modern law: if a widow with children 
wants to marry, she can do so only after having the inventory of the children's property, and after with the new husband, she will assume the obligation - in writing to preserve their goods until they become major (Drimba, 1984).

The situation of the child born inside marriage is regulated in several articles by the law of Hammurabi. The child whose mother is free, has the capacity of free man, the one born from a slave mother and a free father has the capacity of full freed man upon the death of his father and when he is procreated from slave parents he is also slave. Finally, the law takes care of children born from parents who work within the area of prostitution; in this case, if children were raised and educated by an honest family, they cannot ask their return to their natural family. Previous to the law of Hamurabi, the child could be banished without any formality; the code of Hamurabi limits this right only to serious cases and only with the consent of the judge. From this point of view, Babylonian legislation is more advanced than the Israeli one. The banishment of the son brakes any connection between the one banished and his natural family. Adoption of a person stranger to the family is also regulated by law and is known even since the Sumerian age. In fact, it can be of two types: adoption of the child of a concubine and adoption of a total stranger. The children of the concubine, receive, by adoption the legal status of lawful children; in other words, the adoption plays the role of a legitimation. In all cases, adoption requires a written document, in case of adoption of the children of the concubine, has an unilateral character, in case of adoption of a stranger, the legal document has the value of a document concluded between the adopting father and the parents of the child adopted. Adoption of a stranger can be made when the adopter has no family; however, if he wants to form a family, the law gives him the right to alienate the adopted child with the obligation to give his $1 / 3$ of his real estate fortune. If the adopted child denies his adoptive parents, he is turned into slave, chained and sold, and if the adopted is the son of prostitutes, his tongue is cut off. Therefore, adoption creates a connection which cannot be broken as the parents want. Still, from some documents it results that by contract, certain provisions allowing an easy termination of adoption. Thus, a document explained us: "If the adoptive son tells his mother - you are not my mother - he must leave the house, garden and household tools, and if the adoptive mother talks to her son in the same way - you are not my son - he must leave the house, garden....”. In other words it is accepted the possibility of a termination on both sides. In other documents, the possibility of termination of the adoption is given only to the adopting father, not also to the adopted child.

We said that any stranger may be adopted; from the documents it results that slaves can also be adopted. The adopted child has the same rights on the fortune of the adopting father as a lawful successor. (Provided that adoption had lasted until the death of the adopter). Private documents, which were kept, prove other aspects of this institution. Thus, if the adopter has no children, often the formula of adoption is thus drafted (he is not the eldest of our children), as the possibility to procreate lawful children shall take the adopted child the prerogatives of first born. In case the adopter adopts the children of his concubine, in the same time, he forbids his lawful children to challenge the capacity and the rights acquired by the adopted one.

\section{Successions}

Inheritance is divided according to the number of children, girls who received a dowry are excluded from the succession. If the daughter did not receive a dowry, she receives some manly part of the estate (movable) of the father, but not with full ownership , but only in use or her brothers undertake to give her a dowry . If a person 
has been married several times, children of his successive wives will take equal part to inheritance, from this point of view Babylonian law is different from other legislation that grant rights to the children coming from different marriages. A change in this respect and in the Neo-Babylonian law, where the child born of the first marriage receives $2 / 3$, and the one from the second marriage one third of the estate of his father.

Where one of the heirs is a minor, will take over from movables, over his part of the succession, certain values as terhatum for the marriage he will subsequently conclude. Distribution of assets is made amicably or in front of a judge, according to the principles stipulated by the law. Babylonian law does not admit succession by will, in return, the father may, during his life, dispose of his fortune as he wants, provided that a written document is concluded in front of witnesses and, especially, in front of children. At the beginning, the assets of the family formed an inalienable block which the father had to transfer it intact to his successors upon his death. In the era of the code of Hamurabi this situation changed. Thus, the father may advantage some of the successors during his life, by the so-called donations between the living. These donations were called nudunnum and could be offered to the wife, daughters or sons. The father is allowed to share the rest of the fortune in equal shares to his sons, with their obligation to give him an allowance.

The law also takes into account the advantages the father created for the successors. For example, the wife who received a donation, is excluded from the succession by will, as well as the daughter who received a dowry. Moreover, it is pretended that is certain cases, a reserve is guaranteed to the successor. Before Hamurabi, children could be disinherited, without any justification, being enough if the father and mother said - you are not our son - he had to leave the citadel, but subsequently: the exclusion from succession shall be made only with permission from the justice, in cases accepted as serious.

Finally, the law establishes certain rights (1/3 of the virile share) for each daughter entrusted to the God Mardul, as well as the obligation of a dowry for the daughters born from his concubine. Sons born from relations with a concubine shall not have rights to succession unless their father gave them during his life, an adoption document. In the absence of any heir, the succession is different from that of brother's $\mathrm{f}$ the deceased, and in their absence, the uncles from the part of the groom. As for the succession of woman, this are performed according to the same principles, first in line are the children, and in their absence, her brothers .We must underline the fact that a married woman, but with no children, shall not be able to dispose of her assets, upon death of the woman, they return to the family of origin. If, however she has children from the marriage, and, subsequently, becomes widow, these rerun to her family of origin. If she has children from different marriage and meantime she becomes widow, she keeps her personal fortune (dowry) and what she received a virile share after the death of the husband.

She shall not dispose of these assets, which after her death correspond to her children. If between the mother and children occur misunderstandings, the mother may ask the law to allow her to leave the house of her husband, taking with her dowry, that is her wealth from the succession. She has the absolute right to dispose of the dowry; what is left of the dowry shall be distributed to her children. The successors are obliged, as texts show, to maintain the funerary cult of the deceased. This cult does not represent a burden as heavy as in the ancient Roman law or Egyptian one. The successor was only obliged to make the libations requested by the ritual and spill oil on the grave of the deceased. From the evolution of the Babylonian inheritance law we might conclude that in the era of Hamurabi the old genteel conception of the family is 
replaced with an individual conception. Indeed, the idea of preservation of the family's asset, to be transferred to the children, make way for a full liberty of the father. Moreover, the privileged situation of the eldest son advantages the idea of equality, which is manifested particularly clear in the matter of succession.

\section{Criminal Law}

Criminal law in the era of Hamurabi was a slave law; the revenge of the blood, characteristic of primitive societies is replaced, either by a punishment applied by the bodies of the state, either by a compensation which the criminal shall have to pay to the victim. Still, the legislation of Hamurabi bears of few sequelae from the reports of primitive society. Thus, in case of crimes with unknown author, the law establishes a collective responsibility: the territorial jurisdiction where the crime was committed and the leader of the community are obliged to compensate the victim. Still as a genteel reminiscent is also the maintenance of the family responsibility. The sons, daughters of the perpetrator are prosecuted instead of him, principle also known by the ancient Israeli law in all its rigor. This responsibility applies in the following cases provided by the code: - when a person, hitting a pregnant woman causes abortion and her death, he shall be punished with the death of his own daughter: - when an architect built a shaky house which fell and killed the son of the owner, as punishment, the son of the architect shall be killed; - when the son of an insolvable debtor, given as slave to the creditor, was killed due to the bad treatment he received, the creditor shall be punished with the death of his own son.

As a result of the reports of primitive community, we also notice banishment (excommunication) of the perpetrator from that community (such as in case of incest), as well as the application of the law of retaliation (an eye for an eye, a tooth for a tooth, a bone for a bone). Retaliation is allowed only between free citizens, the poorest man and the slave cannot use the law of retaliation towards those located above them. Babylonian legislation provides several categories of crimes. Thus, are the crimes made: a). Against people: murder (punished by death even if caused by negligence or accident); false testimony or complaint(punished by death); b). Service crimes: (for ex., if a doctor is unskilled and by this he causes damages to others, his hand is cut off); a judge establishes an unfair decision may be punished with a fine 12 times higher than the value of the damage etc; c). Crimes against property: stealing is punished with a fine 30 time the value of the asset; is a person steals during a fire, he is burnt; if a person enters through a wall into somebody else's property, he is hanged in that place; if the slave does not recognize his master, he is killed; 4. Crimes against family: adultery is punished by death. Is somebody accuses a woman o adultery but fails to prove it, the following test is made: the woman in thrown into water and if the water received her, so she drowns, she is guilty; but if she makes it alive, she is innocent and the accuser, as punishment, is shaved on his head.

The punishments provided by the code of Hamurabi bear a strong character of class. This also result from the inequality regarding punishments applied for the same crime, in report with the social status of the victim and the guilty. Thus, if a man from an upper class had hit in the face another man of the same level, he would had been obliged to pay him one silver mina. But, is somebody had hit the face of a person of an upper level than his, the guilty had received 60 lashes. If a slave had hit the cheek of a freed man, he would have had his ear cut off. If somebody had hit the pregnant daughter of an auilium and as a result, she would suffer an abortion, he would pay 10 silver sikli; if the same thing happened with the daughter of a common man (muschenum), the fine would drop to 5 sikli, and with a slave, 2 silver sikli. If the hits 
had caused the death of a daughter of an auilum, would have been sentenced to death the daughter of the person who hit; if, as a result of the hit, the daughter of a muschenum died, the business would be reduced to a fine of half a mina. Finally, if a slave died due to the hit, the fine would be reduced to one third of a silver mina.

The same character of class also results from the punishment established by theft. Theft would bring along, the fine for the person who could pay it and the punishment by death for the poor who could not pay the fine for the asset stolen, established at a very high amount. Also by death is paid the theft of slaves of hiding a fugitive slave; it is also severely punished the littlest disobedience towards the master. If the slave says to his master: you are not my master, his master shall cut off his ear.

From those above mentioned, it results that that Babylonian system is remote, priority to support slave organization. In the Babylonian law, the trial was performed by certain colleges of judges, composed by $4,6,8, \ldots$ members and led by the leaders of regions, leaders of cities, village communities. The judges also have administrative positions. Ultimately, the role of judge belongs to the king, who can justify any process and settle it in consequence. No procedural distinction is made between the processes cashed by the victim. As a means of probation were: documents, witnesses, oath. Sometimes they used ordeals; Hammurabi's code states ordeals in case of adultery of the woman and when someone is accused of witchcraft. To strengthen the power of the court ruling, the parties are required duty to not file a lawsuit for a second time. The defendant or plaintiff must undertake in writing, that requirement. In case of violation of these duties, the offender was punished by the judge.

\section{References}

Craiovan, I. (2001), Tratat elementar de teoria generală a dreptului, Editura All Beck.

Dominte, N. R. (2008), Organizarea şi funcționarea societăților comerciale, București, Editura C.H.Beck.

Dravidians-Fichte (1912), Encyclopedia of Religion and Ethics, vol.V, Edinburg.

Drimba, O. (2003) Istoria culturii și civilizației, București, Editura Vestala.

Georgescu, I. L. (2002), Drept Comercial Român, Vol.I, Editura All Beck. 